\title{
Pembayaran Ganti Rugi Tanah Jalan Tol Pekanbaru-Kandis Berdasarkan Asas Kepentingan Umum
}

\author{
Andrizal \\ Fakultas Hukum Universitas Lancang Kuning \\ Umban Sari, Rumbai, Pekanbaru, Riau 28266 \\ 085274877755/andrizal2017@gmail.com
}

\begin{abstract}
The land procurement by the state often raises different opinions about the form or amount of the compensation. The compensation could be done several ways like setting executive compensation, sue the legal problem to the court or others. If the mentioned above do not bring positivelty succeed, then the last alternative is done through deposit for damages to the District Court. This research deals with two problems: 1) how is the implementation of compensation of land procurement by state for highway in Pekanbaru-Kandis; 2) How is the mechanism to compensate the retribution which deposited at the district court. This research approached by legal empirical study and viewed with sociology of law. The results are that the compensation of land authorization by state is done in January 2016 which covers 133 areas. In the case of land mastery dispute and its compensation has been deposited in the district court, it could be taken at court secretariat after the court verdict or based on peace agreement along with cover letter from The Chief Executive of Land Procurement/National Land Agency.
\end{abstract}

Keywords: Land Acquisition; Indemnity and Public Interest; Highway

\begin{abstract}
Abstrak
Pengadaan lahan seringkali menimbulkan perbedaan pendapat tentang bentuk atau jumlah kompensasi. Untuk kompensasi dapat dilakukan seperti pengaturan kompensasi eksekutif, mengajukan tuntutan hukum ke Pengadilan, dan beberapa cara lain yang disepakati. Jika cara seperti tersebut tidak membawa hasil maka alternatif terakhir dengan cara deposit di Pengadilan Negeri. Permasalahan penelitian ini ada dua Pertama, bagaimana pelaksanaan pembayaran ganti rugi jalan raya Pekanbaru-Kandis, Kedua, bagaimana mekanisme kompensasi uang ganti rugi diendapkan di Pengadilan Negeri setempat? Metode penelitian ini adalah hukum sosiologis dengan pendekatan yuridis empiris. Dari hasil penelitian dapat disimpulkan pelaksanaan pembayaran ganti rugi jalan raya Pekanbaru-Kandis telah dilaksanakan pada bulan Januari 2016 seluruhnya sebanyak 133 bidang. Dalam hal objek pengadaan tanah masih dipersengketakan dan uang ganti kerugian sudah dititipkan maka dapat diambil oleh pihak yang berhak di kepaniteraan pengadilan setelah putusan berkekuatan hukum tetap atau berdasarkan akta perdamaian,
\end{abstract}


disertai dengan surat pengantar dari Ketua Pelaksana Pengadaan Tanah (P2T)/Badan Pertanahan Nasional.

Kata kunci: Pembebasan Lahan; Ganti Rugi dan Kepentingan Umum; Jalan Tol

\section{A. PENDAHULUAN}

Istilah "pengadaan tanah" menjadi dikenal setelah lahirnya Keputusan Presiden Nomor 55 Tahun 1993 tentang Pengadaan Tanah Bagi Pelaksanaan Pembangunan Untuk Kepentingan Umum. Istilah pengadaan tanah tersebut digunakan kembali pada Peraturan Presiden Nomor 71 Tahun 2012 tentang Penyelenggaraan Pengadaan Tanah bagi Pembangunan untuk Kepentingan Umum yang telah diubah beberapa kali. Perubahan terakhir melalui Peraturan Presiden Nomor 148 Tahun 2015 tentang Perubahan Keempat atas Peraturan Presiden Nomor 71 Tahun 2012 tentang Penyelenggaraan Pengadaan Tanah bagi Pembangunan untuk Kepentingan Umum. Istilah pengadaan tanah ini merupakan pengganti dari istilah "pembebasan tanah" berdasarkan Undang-Undang Nomor 20 Tahun 1961 tentang Pencabutan Hak-Hak Atas Tanah dan Benda-benda yang Ada di Atasnya mendapat respon kurang positif di masyarakat sehubungan dengan banyaknya permasalahan yang timbul sebagai reaksi terhadap hasil dari pembebasan tanah (Soemardjono dan Samosir, 2000: 35).

Istilah lain dari pembebasan tanah adalah pelepasan hak, keduanya mempunyai kesamaan pengertian, hanya saja arah pandangannya berbeda. Kalau pembebasan tanah sudut pandangnya dari pihak yang mengambil tanah, sedangkan kalau pelepasan hak sudut pandangya dari pihak yang melepaskan hak atas tanah. Pada pembebasan tanah terdapat unsur musyawarah antara pemegang hak atas tanah dengan pihak yang membebaskan tanah, sedangkan dalam pencabutan hak atas tanah mengandung unsur paksaan sepihak dari pemerintah (Endrawati, 2005: 266).

Pembaruan peraturan demi terselenggaranya pengadaan tanah sesuai dengan tujuan pembangunan untuk kepentingan umum terus dilakukan oleh pemerintah. Pengaturan pengadaan tanah diawali dengan lahirnya Undang-Undang Nomor 5 Tahun 1960 tentang Pokok-Pokok Dasar Agraria atau yang seringkali disebut dengan UUPA. Aspek hukum penting dengan diundangkannya UUPA adalah dicanangkannya "Program Landreform" di Indonesia yang bertujuan untuk mempertinggi penghasilan dan taraf hidup para petani penggarap tanah, sebagai landasan atau prasyarat untuk menyelenggarakan pembangunan ekonomi menuju masyarakat yang adil dan makmur berdasarkan Pancasila (Perangin, 1986: 122). Pengaturan pengadaan tanah setelah UUPA, diawali dengan Undang-Undang Nomor 20 Tahun 1961 tentang Pencabutan Hak-hak Tanah dan Benda-benda yang Ada di atasnya, dilanjutkan dengan lahirnya Peraturan Menteri Dalam Negeri Nomor 15 Tahun 1975 tentang Ketentuan-Ketentuan Mengenai Tata Cara Pembebasan Tanah dan dilanjutkan dengan Peraturan Menteri Dalam Negeri Nomor 2 Tahun 1976 tentang Penggunaan Cara Pembebasan Tanah Untuk Kepentingan Pemerintah Bagi Pembebasan Tanah oleh Pihak Swasta. 
Pembaruan peraturan tentang pertanahan kemudian dilakukan kembali. Pembaruan pengaturan pengadaan tanah demi pembangunan untuk kepentingan umum ditandai dengan lahirnya Undang-Undang Nomor 2 Tahun 2012 tentang Pengadaan Tanah Bagi Pembangunan Untuk Kepentingan Umum, disertai dengan aturan pelaksanaannya Peraturan Presiden (Perpres) Nomor 71 Tahun 2012 tentang Penyelenggaraan Pengadaan Tanah Bagi Pembangunan Untuk Kepentingan Umum disertai peraturan perubahannya.

Pembaruan pengaturan juga dilakukan oleh Badan Pertanahan Nasional (BPN) dengan lahirnya Peraturan Kepala Badan Pertanahan Nasional Nomor 5 Tahun 2012 tentang Petunjuk Teknis Pelaksanaan Pengadaan Tanah. Demikian juga turut dilakukan pembaruan terhadap Biaya Operasional Pengadaan Tanah, yakni lahirnya Peraturan Menteri Keuangan Nomor 13/PMK.02/2013 tentang Biaya Operasional dan biaya Pendukung Penyelenggaraan Pengadaan Tanah Bagi Pembangunan Untuk Kepentingan Umum yang Bersumber dari Anggaran Pendapatan dan Belanja Negara (APBN).

Landasan filosofis pembentukan Undang-Undang Nomor 2 Tahun 2012 diundangkan pada bulan Januari 2012 sebagai pembaruan hukum diharapkan mampu memberikan landasan penyelesaian bagi pelaksanaan pengadaan tanah di Indonesia. Berbagai konflik dalam pengadaan tanah diharapkan mampu diminimalisir dengan munculnya undang-undang ini sehingga pengadaan tanah dapat dilakukan secara cepat, namun tetap dengan memperhatikan hak-hak dari pemegang hak atas tanah yang tanahnya terkena pengadaan tanah bagi pembangunan untuk kepentingan umum. Landasan filosofis ini sesuai dengan teori Savigny yang menyatakan, "hukum timbul bukan karena perintah penguasa (instruktif) atau karena kebiasaan, tetapi karena perasaan keadilan yang terletak di dalam jiwa bangsa (volkgeist) itulah menjadi sumber hukum (Darmodihardjo dan Shidarta, 2004: 105).

Pengadaan tanah bagi pembangunan untuk kepentingan umum secara prinsip mengandung fungsi sosial. Fungsi ini berarti sesuatu dapat dimanfaatkan oleh orang lain dalam kehidupan sosial atau kehidupan bersama. Fungsi sosial hak atas tanah maksudnya adalah setiap hak atas tanah dapat dimanfaatkan oleh orang lain kalau dibutuhkan, bukan hanya oleh pemiliknya sendiri (Soemardjono dan Samosir, 2000: 40). Adrian Sutedi (2008: 75) manyatakan terkait dengan fungsi sosial tersebut:

"konsep fungsi sosial hak atas tanah menurut UUPA tidaklah berpangkal pada hak yang bersifat individualistis. Akan tetapi, UUPA beranggapan bahwa konsepsi fungsi sosial itu adalah sebagai jalan kompromi antara kepentingan individu dengan kepentingan masyarakat. Inilah sifat hak atas tanah yang dualistis."

Sementara itu, AP. Parlindungan (1989: 84) berpendapat bahwa:

"prinsipyang terdapat dalam Pasal 6 UUPA Nomor 5 Tahun 1960 tersebut adalah prinsip dwi tunggal. Artinya, di dalam hak seseorang itu terkandung juga hak 
masyarakat, semakin kuat tekanan dari masyarakat (kepentingan umum) maka kepentingan perorangan harus mengalah".

Walaupun hak atas tanah yang dipunyai oleh seseorang atau badan hukum berfungsi sosial, namun hak atas tanah tersebut sesuai dengan hukum tanah nasional yang dilindungi dari gangguan pihak manapun dan hak atas tanah tersebut tidak boleh dirampas dengan sewenang-wenang atau melawan hukum termasuk oleh penguasa. Perlindungan hukum terhadap hak atas tanah seseorang, dapat dicermati dari Pasal 28 H Ayat (4) Undang-Undang Dasar (UUD) Tahun 1945 menyebutkan "Setiap orang berhak mempunyai hak milik pribadi dan hak milik tersebut tidak boleh diambil alih secara sewenang-wenang oleh siapa pun". Terkait hal ini menurut Oloan Sitorus dan Dayat Limbong Rakyat yang diminta menyerahkan tanahnya untuk proyek pembangunan berhak untuk memperoleh pengayoman dari pejabat birokrasi (Sitorus dan Limbong, 2004: 13).

Pelaksanaan pembangunan berdasarkan asas kepentingan umum dilakukan oleh pemerintah dengan seperangkat peraturan perundang-undangan yang melegitimasi tindakan pemerintah dalam mengambil (membebaskan atau mencabut) hak atas tanah yang dikuasai oleh masyarakat, tentu dengan memberikan ganti rugi yang layak. Landasan hukum yang dipakai oleh pemerintah antara lain UndangUndang Nomor 2 Tahun 2012 tentang Pengadaan Tanah Bagi Pembangunan Untuk Kepentingan Umum, Perpres Nomor 71 Tahun 2012 tentang Penyelenggaraan Pengadaan Tanah Bagi Pembangunan Untuk Kepentingan Umum yang telah diubah beberapa kali terakhir dengan Peraturan Presiden Nomor 148 Tahun 2015 tentang Perubahan Keempat atas Peraturan Presiden Nomor 71 Tahun 2012 tentang Penyelenggaraan Pengadaan Tanah bagi Pembangunan untuk Kepentingan Umum. Kemudian Peraturan Kepala BPN Nomor 5 Tahun 2012 tentang Petunjuk Teknis Pelaksanaan Pengadaan Tanah dan Peraturan Mahkamah Agung Nomor 3 Tahuh 2016 tentang Tata Cara Pengajuan Keberatan dan Penitipan Ganti Kerugian Ke Pengadilan Negeri dalam Pengadaan Tanah Bagi Pembangunan Untuk Kepentingan Umum.

Tidak dapat dipungkiri bahwa konflik sangat rentan muncul dalam pelaksanaan pengadaan tanah. Masalah pengadaan tanah tentu saja menyangkut hajat hidup orang banyak bila dilihat dari sisi kebutuhan pemerintah akan tanah untuk keperluan pembanguan. Satu-satunya jalan yang dapat ditempuh agar keperluan akan tanah terpenuhi adalah dengan membebaskan tanah milik rakyat, baik yang dikuasai hukum adat maupun hak-hak yang melekat di atasnya (Soimin, 2004: 75).

Proses pengadaan tanah sering terjadi perbedaan pendapat mengenai bentuk dan atau besaran ganti kerugian. Untuk menetapkan ganti kerugian yang dapat disepakati oleh para pihak, dapat dilakukan beberapa cara seperti penetapan ganti rugi oleh panitia pengadaan tanah, pengajuan gugatan ke Pengadilan, dan beberapa cara yang lain agar dapat timbul suatu kesepakatan mengenai ganti rugi tersebut. Apabila dengan cara-cara seperti yang tersebut masih tetap saja tidak membawa hasil 
maka dapat digunakan alternatif penyelesaian dengan cara konsinyasi atau penitipan ganti kerugian di Pengadilan Negeri. Saat ini konsinyasi sering digunakan untuk menyelesaikan sengketa ganti rugi pengadaan tanah, namun dalam penerapannya masih banyak pihak yang tidak setuju. Konsinyasi atau penitipan uang ganti kerugian bagi pembangunan untuk kepentingan umum telah diatur di dalam Undang-Undang Nomor 2 Tahun 2012 tentang Pengadaan Tanah bagi Pembangunan Untuk Kepentingan Umum.

Pada Pasal 43 Undang-Undang Nomor 2 Tahun 2012, Pasal 100 Ayat (1) Perpres Nomor 71 Tahun 2012, dan Pasal 42 Ayat (1) Peraturan Kepala BPN Nomor 5 Tahun 2012 akibat hukum yang akan dialami oleh pemegang hak atas tanah adalah jika sudah terdapat penitipan uang ganti rugi (UGR) ke Pengadilan Negeri kepemilikan atau hak atas tanah dari pihak yang berhak menjadi terhapus demi hukum. Alat bukti haknya dinyatakan tidak berlaku dan tanahnya menjadi tanah yang dikuasai langsung oleh negara.

Pasal 44 Ayat (1) dan (2) Peraturan Kepala BPN Nomor 5 Tahun 2012, menyatakan:

(1) Hapusnya hubungan hukum antara pihak yang berhak dengan tanahnya sebagaimana dimaksud dalam Pasal 42 dan Pasal 43, terhadap tanah yang sudah terdaftar Kepala Kantor Pertanahan selanjutnya melakukan pencatatan hapusnya hak dalam Buku Tanah dan daftar umum lainnya.

(2) Hapusnya hubungan hukum antara pihak yang berhak dengan tanahnya sebagaimana dimaksud Ayat (1), terhadap tanah yang belum terdaftar, Ketua Pelaksana Pengadaan Tanah (P2T) menyampaikan pemberitahuan tentang hapusnya hubungan hukum dan disampaikan kepada lurah/kepala desa atau nama lain, camat atau nama lain dan pejabat yang berwenang yang mengeluarkan surat, untuk selanjutnya dicatat pada alas hak/bukti perolehan hak dan dalam buku administrasi kantor kelurahan/desa atau nama lain atau kecamatan.

Bila dicermati pasal demi pasal Undang-Undang Nomor 2 Tahun 2012 tentang Pengadaan Tanah Bagi Pembangunan Untuk Kepentingan Umum khususnya dalam pelaksanaan pembayaran ganti kerugian tanah, bangunan dan tanaman pemerintah dalam hal ini pihak yang memerlukan tanah sangat kuat posisinya dengan asas kepentingan umum.

Penelitian terkait tentang pengadaan tanah dalam rangka pembangunan jalan tol Solo Kertosono pernah dilaksanakan sejak tahun 2007. Hasil penelitian tersebut menjelaskan bahwa pengadaan tanah sampai dengan bulan Desember tahun 2014 telah mencapai $90 \%$ dari total tanah yang dibutuhkan. Berdasarkan hal tersebut maka proses pengadaan tanah dalam rangka pembangunan jalan tol Solo Kertosono ruas Solo Mantingan di wilayah Kabupaten Sragen dilaksanakan berdasarkan Perpres Nomor 36 Tahun 2005 tentang Pengadaan Tanah Bagi Pelaksanaan Pembangunan 
Untuk Kepentingan Umum yang telah dirubah dengan Perpres Nomor 65 Tahun 2006 tentang Perubahan Atas Perpres Nomor 36 Tahun 2005 serta peraturan pelaksanaannya, yaitu Peraturan Kepala BPN Nomor 3 Tahun 2007 tentang Ketentuan Pelaksanaan Perpres Nomor 36 Tahun 2005 tentang Pengadaan Tanah Bagi Pelaksanaan Pembangunan Untuk Kepentingan Umum sebagaimana telah diubah dengan Perpres Nomor 65 Tahun 2006 tentang Perubahan Atas Perpres Nomor 36 Tahun 2005.

Penelitian yang dilakukan dalam makalah ini menggunakan peraturan perundang-undangan yang terbaru, yaitu Undang-Undang Nomor 2 Tahun 2012 tentang Pengadaan Tanah Bagi Pembangunan Untuk Kepentingan Umum, Perpres Nomor 71 Tahun 2012 tentang Penyelenggaraan Pengadaan Tanah Bagi Pembangunan Untuk Kepentingan Umum yang telah diubah beberapa kali terakhir dengan Peraturan Presiden Nomor 148 Tahun 2015 tentang Perubahan Keempat atas Peraturan Presiden Nomor 71 Tahun 2012 tentang Penyelenggaraan Pengadaan Tanah bagi Pembangunan untuk Kepentingan Umum. Selain itu juga menggunakan Peraturan Kepala BPN Nomor 5 Tahun 2012 tentang Petunjuk Teknis Pelaksanaan Pengadaan Tanah dan PERMA Nomor 3 Tahun 2016 tentang Tata Cara Pengajuan Keberatan dan Penitipan Ganti Kerugian ke Pengadilan Negeri Dalam Pengadaan Tanah Bagi Pembangunan Untuk Kepentingan Umum.

Berdasarkan Pasal 42 Ayat (1), Undang-Undang Nomor 2 Tahun 2012 tentang Pengadaan Tanah Bagi Pembangunan Untuk Kepentingan Umum dalam hal pihak yang berhak menolak bentuk dan/atau besarnya ganti kerugian berdasarkan hasil musyawarah sebagaimana dimaksud dalam Pasal 37, atau putusan Pengadilan Negeri/Mahkamah Agung sebagaimana dimaksud dalam Pasal 38, ganti kerugian dititipkan di pengadilan negeri setempat. Ayat (2) penitipan ganti kerugian selain sebagaimana dimaksud pada Ayat (1), juga dilakukan terhadap pihak yang berhak menerima ganti kerugian yang tidak diketahui keberadaannya; atau objek pengadaan tanah yang akan diberikan ganti kerugian dalam kriteria berikut:

1. Sedang menjadi objek perkara di pengadilan

2. Masih dipersengketakan kepemilikannya

3. diletakkan sita oleh pejabat yang berwenang atau

4. Menjadi jaminan di bank.

Pada Pasal 43 Undang-Undang Nomor 2 Tahun 2012, Pasal 100 Ayat (1) Perpres Nomor 71 Tahun 2012, dan Pasal 42 Ayat (1) Peraturan Kepala BPN Nomor 5 Tahun 2012 akibat hukum yang akan dialami oleh pemegang hak atas tanah adalah jika sudah terlaksana penitipan UGK ke Pengadilan Negeri kepemilikan atau hak atas tanah dari pihak yang berhak menjadi hapus demi hukum. Alat bukti haknya dinyatakan tidak berlaku dan tanahnya menjadi tanah yang dikuasai langsung oleh negara. 
Dilihat dari hal tersebut, asas kepentingan umum selalu diutamakan dari pada kepentingan pribadi dan kelompok. Bahkan berdasarkan Pasal 43 Undang-Undang No. 2 Tahun 2012 tentang Pengadaan Tanah Bagi Pembangunan Untuk Kepentingan Umum hak-hak pribadi dapat dicabut secara paksa oleh negara, dengan dalil untuk kepentingan umum.

Berdasarkan uraian di atas penelitian ini memfokuskan pada kajian hukum yang berkaitan dengan Pelaksanaan Pembayaran Ganti Rugi Tanah Jalan Tol Pekanbaru-Kandis. Kajian ini merumuskan permasalahan sebagai berikut:

1. Bagaimana pelaksanaan pembayaran ganti rugi tanah jalan tol PekanbaruKandis berdasarkan asas kepentingan umum?

2. Bagaimana mekanisme pengambilan uang ganti rugi yang telah dititipkan di Pengadilan Negeri setempat?

\section{B. METODE PENELITIAN}

Penelitian ini menggunakan jenis penelitian hukum sosiologis dengan metode pendekatan yuridis-empiris. Maksudnya untuk menjelaskan penerapan peraturan perundang-undangan di bidang pengadaan tanah bagi pembangunan untuk kepentingan umum khususnya pelaksanaan pembayaran uang ganti rugi tanah jalan Tol Pekanbaru-Kandis berdasarkan Undang-Undang Nomor 2 Tahun 2012 tentang Pengadaan Tanah Bagi Pembangunan Untuk Kepentingan Umum yang telah diubah beberapa kali terakhir dengan Peraturan Presiden Nomor 148 Tahun 2015 tentang Perubahan Keempat atas Peraturan Presiden Nomor 71 Tahun 2012 tentang Penyelenggaraan Pengadaan Tanah bagi Pembangunan untuk Kepentingan Umum.

Lokasi penelitian dilakukan di wilayah hukum Kota Pekanbaru. Alasan penulis menentukan lokasi ini sehubungan banyaknya permasalahan dalam pengadaan tanah terutama dalam pelaksanaan pembayaran uang ganti kerugian (UGK) kepada pihak yang berhak. Akibatnya terpaksa dilakukan penitipan/konsinyasi ke Pengadilan Negeri Pekanbaru sebanyak 6 orang dengan 7 bidang tanah yang sedang berjalan prosesnya di sejak bulan Agustus 2016 yang diteliti.

Populasi dalam penelitian ini terdiri dari Kementerian Pekerejaan Umum dan Perumahan Rakyat (PUPR) dalam hal ini Pejabat Pembuat Komitmen (PPK) jalan tol Pekanbaru-Kandis, Kepala Badan Pertanahan Kota Pekanbaru selaku Ketua Pelaksana Pengadaan Tanah (P2T) trase jalan tol Pekanbaru-Kandis, Ketua dan Panitera Pengadilan Negeri Pekanbaru, dan pihak yang berhak atas tanah yang uang ganti kerugiannya dititipkan di Penegadilan Negeri Pekanbaru.

Sampel yang diambil dalam penelitian terdiri dari Kementerian PUPR dalam hal ini Pejabat Pembuata Komitmen (PPK) jalan tol Pekanbaru-Kandis, Kepala Badan Pertanahan Kota Pekanbaru selaku Ketua Pelaksana Pengadaan Tanah (P2T) trase jalan tol Pekanbaru-Kandis, Ketua Pengadilan Negeri Pekanbaru, Panitera dan pihak yang berhak atas tanah yang uang ganti kerugiannya dititipkan di Pengadilan Negeri 
Pekanbaru. Gambaran populasi dan sampel dalam penelitian ini dapat dilihat pada tabel berikut.

Tabel 1. Populasi dan Sampel

\begin{tabular}{|c|c|c|c|c|}
\hline No & Responden & Populasi & Sampel & Persentase (\%) \\
\hline 1. & $\begin{array}{l}\text { Pejabat Pembuat } \\
\text { Komitmen (PPK) selaku } \\
\text { perwakilan Kementerian } \\
\text { PUPR }\end{array}$ & 1 & 1 & 100 \\
\hline 2. & $\begin{array}{l}\text { Kepala Kantor BPN Kota } \\
\text { Pekanbaru, }\end{array}$ & 1 & 1 & 100 \\
\hline 3. & $\begin{array}{l}\text { Ketua dan/atau Panitera } \\
\text { Pengadilan Negeri } \\
\text { Pekanbaru }\end{array}$ & 1 & 1 & 100 \\
\hline 4. & $\begin{array}{l}\text { Pihak yang berhak atas } \\
\text { tanah yang tidak di } \\
\text { ketahui keberadaannya } \\
\text { dan yang tidak setuju } \\
\text { besaran nilai ganti rugi } \\
\text { dan uang ganti ruginya } \\
\text { dititipkan di Pengadilan } \\
\text { Negeri Pekanbaru }\end{array}$ & 7 & 2 & 28,57 \\
\hline
\end{tabular}

Data yang telah dikumpulkan diolah dengan cara mengelompokkan dan memilah data yang didapat disajikan dalam bentuk uraian kalimat atau narasi yang jelas dan rinci. Data kepustakaan diinventaris sesuai kebutuhan referensi berupa teori atau penjelasan normatif dideskripsikan dalam bentuk narasi. Langkah selanjutnya penulis melakukan interpretasi data, menghubungkan satu data dengan data yang lainnya. Kemudian penulis menghubungkan dengan teori-teori dan ketentuan hukum yang berkaitan dengan permasalahan. Teknik pengambilan kesimpulan dilakukan dengan cara induktif, yaitu metode penarikan kesimpulan dari ketentuan yang bersifat khusus ke yang besifat umum, yaitu dari kenyataankenyataan yang ada dengan teori-teori yang ada.

\section{HASIL DAN PEMBAHASAN}

1. Pelaksanaan pembayaran ganti rugi tanah jalan tol Pekanbaru-Kandis berdasarkan asas kepentingan umum

Undang-Undang Nomor 2 Tahun 2012 (UU PTUP) tentang Pengadaan Tanah Bagi Pembangunan Untuk Kepentingan Umum mengatur bahwa musyawarah dilaksanakan dalam dua tahap. Tahap pertama, konsultasi publik yang diatur dalam 
ketentuan Pasal 19 sampai dengan Pasal 21. Konsultasi publik dilakukan untuk memperoleh kesepakatan lokasi rencana pembangunan. Pelaksanaannya dibatasi dalam jangka waktu 90 hari. Tahap kedua, musyawarah penetapan ganti rugi yang diatur dalam ketentuan Pasal 37 sampai dengan Pasal 39. Musyawarah tersebut dilaksanakan antara BPN selaku Pelaksana Pengadaan Tanah (P2T) Jalan Tol Pekanbaru-Kandis dengan pihak yang berhak paling lama 30 hari sejak hasil penilaian dari penilai disampaikan kepada BPN/P2T.

Pelaksanaan pembayaran UGK objek pengadaan tanah jalan tol PekanbaruKandis diberikan langsung kepada pihak yang berhak. Ganti kerugian diberikan kepada pihak yang berhak berdasarkan hasil penilaian dari Appraisal/KJPP yang ditetapkan dalam musyawarah dan/atau putusan Pengadilan Negeri/Mahkamah Agung. Pada saat pemberian ganti kerugian pihak yang berhak menerima ganti kerugian wajib untuk:

a. Melakukan pelepasan hak

b. Menyerahkan bukti penguasaan atau kepemilikan objek pengadaan tanah kepada instansi yang memerlukan tanah melalui Lembaga Pertanahan.

Bukti yang dimaksud merupakan satu-satunya alat bukti yang sah menurut hukum dan tidak dapat diganggu gugat di kemudian hari. Pihak yang berhak menerima ganti kerugian bertanggung jawab atas kebenaran dan keabsahan bukti penguasaan atau kepemilikan yang diserahkan. Tuntutan pihak lain atas objek pengadaan tanah yang telah diserahkan kepada instansi yang memerlukan tanah menjadi tanggung jawab pihak yang berhak menerima ganti kerugian.

Dalam hal pihak yang berhak menolak bentuk dan/atau besarnya ganti kerugian berdasarkan hasil musyawarah atau putusan Pengadilan Negeri/ Mahkamah Agung, ganti kerugian dititipkan di Pengadilan Negeri setempat.

Penitipan ganti kerugian di Pengadilan Negeri juga dapat dilakukan terhadap:

a. Pihak yang berhak menerima ganti kerugian tidak diketahui keberadaannya, atau

b. Objek pengadaan tanah yang akan diberikan ganti kerugian:

1) Sedang menjadi objek perkara di pengadilan

2) Masih dipersengketakan kepemilikannya

3) Diletakkan sita oleh pejabat yang berwenang atau

4) Menjadi jaminan di bank

Oleh karena itu, UU PTUP tidak mengatur masalah ganti rugi lewat mufakat. Ganti rugi akan menggunakan penafsiran pemerintah dan patokan harga tidak dapat dikompromikan. Jika terjadi sengketa maka akan lansung di bawa ke pengadilan. Hanya saja, Undang-Undang tersebut berpotensi melegalkan perampasan tanah oleh perusahaan-perusahaan swasta dan negara di mana didalamnya dengan jelas memprioritaskan kepentingan pemilik modal ketimbang kepentingan rakyat. 
Pengadaan tanah untuk kepentingan umum dalam perkembangannya meliputi salah satu dari dua jenis kepentingan pembangunan, yaitu pembangunan untuk kepentingan rakyat dan pembangunan untuk kepentingan perusahaan (swasta). Banyaknya pengadaan tanah yang dikemas untuk kepentingan umum, pada hakekatnya justru jatuh untuk kepentingan pemilik modal. Keadaan yang demikian bertentangan dengan filosofi hukum, yakni aspek kepastian, keadilan, dan kemanfaatan yang seharusnya diberikan kepada rakyat tanpa ada pembedaan.

Oleh karena itu, prinsip-prinsip kepentingan umum dalam UU PTUP dan Perpres Nomor 71 Tahun 2012 perlu dianalisis berdasarkan rasa keadilan masyarakat dan penentuan besarnya ganti rugi. Prinsip-prinsip perolehan tanah untuk pembangunan bagi kepentingan umum harus meliputi:

a. kepastian atas terselenggaranya proses pembangunan untuk kepentingan umum bukan untuk swasta atau bisnis.

b. keterbukaan publik dalam proses pembangunan untuk kepentingan umum.

c. penghormatan hak atas tanah.

d. keadilan bagi yang menyerahkan atau melepaskan hak atas tanah bagi kepentingan umum.

Proses musyawarah dalam Perpres Nomor 71 Tahun 2012 tidak memberikan rasa keadilan untuk menentukan besar dan bentuk ganti rugi kepada pemegang hak atas tanah yang tanahnya dibebaskan untuk kepentingan umum. Penerapan asas musyawarah untuk menentukan besar dan bentuk ganti rugi para pihak tidak berada dalam posisi seimbang. Pemegang hak atas tanah diposisikan sebagai pihak yang lemah, sedangkan pemerintah berada dalam posisi yang kuat. Hal itu, dapat dibuktikan dengan kecilnya kesempatan pemegang hak atas tanah untuk menyatakan kehendaknya dalam menentukan ganti rugi.

Menurut Pasal 76 Perpres Nomor 148 Tahun 2015 tentang Perubahan Keempat Perpres Nomor 71 Tahun 2012 pada Pasal 76 menyatakan bahwa ganti kerugian dalam bentuk uang diberikan dalam bentuk mata uang rupiah. Pemberian ganti kerugian dalam bentuk uang dilakukan oleh instansi yang memerlukan tanah berdasarkan validasi dari Ketua Pelaksana Pengadaan Tanah atau pejabat yang ditunjuk. Validasi dari ketua pelaksana pengadaan tanah atau pejabat yang ditunjuk dilaksanakan dalam waktu paling lama 3 (tiga) hari kerja sejak berita acara kesepakatan bentuk ganti kerugian. Pemberian ganti kerugian dilakukan bersamaan dengan pelepasan hak oleh pihak yang berhak. Pemberian ganti kerugian dilakukan dalam waktu paling lama 7 (tujuh) hari kerja sejak penetapan bentuk ganti kerugian oleh pelaksana pengadaan tanah. Pasal 121 A Perpres ini juga menegaskan, pengadaan tanah bagi pembangunan yang dilaksanakan oleh badan usaha swasta, dilakukan langsung dengan cara jual beli, tukar-menukar, atau cara lain yang disepakati oleh pihak yang berhak dengan badan usaha swasta. 
Pengadaan tanah untuk kepentingan umum merupakan prosedur yang menyangkut persoalan esensial dalam upaya penegakan hukum yang berujung pada tercapainya keadilan. Dalam konteks sosial, sesungguhnya prosedur atau mekanisme merupakan sebuah kontrak sosial yang merupakan kesepahaman antara regulator dengan rakyat mengenai urut-urutan kegiatan yang harus ditempuh dalam suatu kegiatan. Dalam penyusunan prosedur menurut Nonet dan Selznick harus bersifat jelas (tidak multitafsir), sederhana dan mudah dilaksanakan (tidak birokratik), bertujuan jelas, mengedepankan kemaslahatan masyarakat daripada kepentingan regulator (Nonet dan Selznick, 2003: 54).

Implikasi yang timbul, harus dicermati dari sekian variabel dari proses panjang prosedur dan eksekusinya. Berbicara hukum tidak hanya terbatas pada apa yang tertuang dalam teks, seperti hukum alam atau matematis segala sesuatu terkuantifikasi. Dalam penafsiran bukan menggunakan logika peraturan semata, melainkan kenyataan yang ada di masyarakat.

Berkaitan dengan kebijakan (policy) maka suatu kebijakan yang diambil pada tataran, nasional, regional, lokal dalam pengadaan tanah untuk kepentingan pembangunan wajib mempertimbangkan produk hukum apa yang akan dihasilkan, artinya bagaimana wujud pengkaidahan kebijakan yang akan dibuat, kemana hukum hendak diarahkan, variabel apa yang secara signifikan dapat mengubah hukum yang diberlakukan. Bagaimana implikasi kebijakan dapat dikatakan sebagai kebijakan yang tidak implementatif, otoriter, tidak realistik, terlepas dari nilai-nilai keadilan dan etika berbangsa dan bernegara (principle of good governence).

Salah satu permasalahan muncul sebagai akibat dari pengadaan tanah bagi pembangunan untuk kepentingan adalah terhadap petani yang kehilangan tanahnya harus berubah menjadi non petani: buruh tani, buruh pabrik, penarik becak, buruh bangunan yang sebelumnya tidak pernah terbayangkan. Apakah sengaja atau tidak mengabaikan kalkulasi kerugian akibat pengadaan tanah terhadap perubahan tata guna lahan yang semula sawah beririgasi teknis yang dulu dibiayai dengan utang luar negeri menjadi peruntukan lain, misalnya bendungan pengairan, prasarana/sarana jaringan transportasi darat. Berapa biaya yang harus dikeluarkan pemerintah untuk melakukan perubahan peta tata ruang nasional/ provinsi/kabupaten/kota sebagai akibat dari pengadaan tanah atau sebaliknya.

Berapa biaya yang harus dikeluarkan oleh pihak yang memerlukan tanah untuk pengamanan infrastruktur yang akan atau sedang dibangun oleh aparatur keamanan akibat mendapatkan resistensi atau penolakan warga masyarakat kerena sebab tertentu. Bila dilakukan dengan pendekatan legal-positivistik akan sia-sia, karena ketidakmampuan mengungkap akar persoalan, mengapa setiap aktifitas pengadaan tanah pada tataran implementatif mengalami resistensi dari publik.

Persoalan pengadaan tanah bagi pembangunan untuk kepentingan umum hanyalah berakar pada pengalokasian anggaran untuk pembayaran ganti kerugian 
kepada subyek eks pemegang hak atas tanah sebagaimana diatur dalam Peraturan Menteri Keuangan Nomor 58/PMK.02/2008. Tidak pernah terpikirkan bagaimana implikasi sosial-ekonomi-budaya perubahan hidup eks pemegang hak atas tanah sesudah tanahnya diambil oleh pemerintah.

Mengacu pada ketentuan Pasal 36 dan Pasal 37 Undang-Undang Nomor 39 Tahun 1999 tentang Hak Asasi Manusia maka kaidah hukum yang mengatur mengenai pengadaan tanah bagi pembangunan untuk kepentingan umum berupa undang-undang bukan Perpres sebagaimana selama ini berlaku. Mengingat masalah hak atas tanah merupakan sesuatu yang bersifat fundamental serta merupakan bagian dari Hak Asasi Manusia. Tidak dibenarkan hak atas tanah seseorang termasuk didalamnya hak ulayat (hak adat) atas tanah diambil oleh pihak lain apalagi secara paksa dengan mengabaikan aspirasi si subyek hak atas tanah.

Dengan dasar perhitungan sebagaimana diatur dalam Pasal 15 Undang-Undang Nomor 2 Tahun 2012, yaitu dasar perhitungan besarnya nilai ganti kerugian didasarkan atas Penilaian Lembaga/Tim Penilai harga tanah yang ditunjuk oleh Panitia. Bentuk dan/atau besarnya ganti rugi pengadaan tanah secara langsung ditetapkan berdasarkan musyawarah antara instansi pemerintah yang memerlukan tanah dengan pemilik.

Sehubungan dengan hal tersebut maka perlu kiranya dikemukakan pendapat Boedi Harsono bahwa hak milik atas tanah yang diperlukan itu dilepaskan oleh pemiliknya setelah ia menerima uang ganti kerugian dari pihak yang mengadakan pembebasan tanah. Ganti rugi tersebut sudah barang tentu sama dengan harga tanah sebenarnya. Jadi, jelas bahwa pengertian uang ganti rugi itu sama dengan harga tanah (Harsono, 1997: 166).

Penilai merupakan profesi yang secara nasional diatur dan berada di bawah Kementerian Keuangan. Mereka adalah orang perseorangan yang melakukan penilaian secara independen dan profesional yang telah mendapat izin praktik penilaian dari Menteri Keuangan dan telah mendapat lisensi dari Lembaga Pertanahan untuk menghitung nilai/harga objek pengadaan tanah. Besar nilai ganti kerugian sebagai hasil penilaian kemudian disampaikan ke BPN/Pelaksana Pengadaan Tanah (P2T) dan dijadikan dasar atau acuan pada saat muswarah penetapan bentuk dan atau besaran ganti kerugian dengan masyarakat. Hasil musyawarah penetapan ganti kerugian antara masyarakat dengan BPN/Pelaksana Pengadaan Tanah akan bermuara kepada dua hasil akhir, yaitu sepakat besarnya ganti kerugian berdasarkan hasil kerja Penilai atau tidak sepakat. Bagi masyarakat yang tidak sepakat dapat mengajukan keberatan ke pengadilan negeri.

Dalam persidangan di pengadilan negeri pihak yang berkepentingan (bisa dari pihak pemerintah/instansi atau pihak yang berhak) dapat mengajukan saksi ahli sebagai pembanding penilaian. Dari penjelasan tersebut memang tidak tergambarkan bagaimana hakim memformulasikan perhitungan hingga sampai keluar putusan 
besaran ganti kerugian. Hal ini yang banyak menjadi pertanyaan oleh pihak yang tidak setuju dengan putusan pengadilan negeri. Namun, dalam persidangan tersebut hakim dapat mendengar dari saksi ahli yang diajukan para pihak yang berkepentingan untuk didengar pendapatnya sebagai pembanding atas penilaian ganti kerugian yang dianggap tidak wajar atau tidak layak tersebut.

Dalam soal kewenangan, Pasal 73 Perpres Nomor 71 Tahun 2012 yang merupakan delegasian UU PTUP juga tidak menyatakan hal yang berbeda dari Pasal 38 UU PTUP. Pasal tersebut bahkan mengulang kembali bunyi Pasal 38 UU PTUP. Adapun di dalam Peraturan Kepala BPN Nomor 5 Tahun 2012 tidak dibahas lagi mengenai kewenangan pengadilan negeri dalam memutus keberatan atas penetapan besarnya ganti kerugian yang diajukan pihak yang berhak, tetapi lebih banyak membahas mengenai penitipan ganti kerugian di pengadilan negeri. Oleh karenanya anggapan bahwa pengadilan negeri telah melampaui kewenangan (ultra vires) dalam ikut menentukan besaran ganti kerugian tidak ditemukan dalam peraturan perundang-undangan.

Secara yuridis pengadilan negeri dibenarkan dan sah memutus besarnya ganti kerugian dalam perkara pembebasan lahan. Begitu pun pada tingkat pengadilan yang lebih tinggi, yaitu Kasasi ke Mahkamah Agung. Adanya peluang upaya hukum yang lebih luas dibanding peraturan sebelumnya dalam hal keberatan nilai ganti kerugian merupakan langkah maju dalam proses pembebasan lahan untuk pembangunan kepentingan umum.

Hal ini menggambarkan kesungguhan pemerintah dalam menghormati hakhak warga negaranya termasuk dalam kepemilikan tanah, sesuai tujuan pengadaan tanah dalam UU PTUP itu sendiri (Pasal 3): "Pengadaan Tanah untuk Kepentingan Umum bertujuan menyediakan tanah bagi pelaksanaan pembangunan guna meningkatkan kesejahteraan dan kemakmuran bangsa, negara, dan masyarakat dengan tetap menjamin kepentingan hukum Pihak yang Berhak."

Instansi yang memerlukan tanah dapat mengajukan permohonan Penitipan Ganti Kerugian kepada Pengadilan dalam hal memenuhi satu atau lebih keadaan berikut ini:

a. pihak yang berhak menolak bentuk dan/atau besarnya ganti kerugian berdasarkan hasil musyawarah penetapan ganti kerugian tetapi tidak mengajukan keberatan ke pengadilan.

b. pihak yang berhak menolak bentuk dan/atau besarnya ganti kerugian berdasarkan putusan pengadilan yang telah memperoleh kekuatan hukum tetap.

c. pihak yang berhak tidak diketahui keberadaannya.

d. objek pengadaan tanah yang akan diberikan ganti kerugian:

1) sedang menjadi objek perkara di pengadilan.

2) masih dipersengketakan kepemilikannya. 
3) diletakkan sita oleh pejabat yang berwenang.

4) menjadi jaminan di bank.

Bentuk ganti kerugian yang dapat dititipkan di Pengadilan berupa uang dalam mata uang rupiah. Permohonan penitipan ganti kerugian diajukan secara tertulis dalam bahasa Indonesia oleh pemohon atau kuasanya.

Berdasarkan hasil wawancara dengan Bapak Dr. Marsyudin Nainggolan, S.H., M.H. selaku Ketua Pengadilan Negeri Pekanbaru dan Bapak Zailani Sihab, S.H. selaku Panitera Pengadilan Negeri Pekanbaru mereka menyatakan telah ada masuk penitipan/konsinyasi uang ganti kerugian tanah masyarakat yang tidak setuju besaran nilai ganti kerugiaanya, dan uang ganti kerugian yang tidak diketahui keberadaanya juga telah dititipkan di Rekening Pengadilan Negeri Pekanbaru yang jumlah yang dimohonkan penitipan ada 7 bidang tanah yang digunakan untuk pembangunan jalan tol Pekanbaru-Kandis.

Adapun yang 7 bidang tersebut ada 5 bidang tidak diketahui keberadaan pemiliknya sehingga 2 kali dipublikasikan/diumumkan di Koran Riau Pos dan ditempelkan pengumuman di Kantor Wali Kota Pekanbaru. Setelah permohonan kita terima dan permohonan itu tentu kita teliti dahulu apakah sudah lengkap dengan alat bukti yang diajukan oleh pemohon dalam hal ini adalah Kementerian PUPR yang diwakili oleh Pejabat Pembuat Komitmen (PPK).

Setelah berkas dinyatakan lengkap sesuai dengan Peraturan Mahkamah agung Nomor 3 Tahun 2016, baru dikeluarkan penetapan sebagai berikut:

a. Ketua Pengadilan Negeri Pekanbaru mengeluarkan Penetapan Nomor 01/Pdt.P/Kons/2016/PN.Pbr tanggal 12 November 2016 dan Surat Perintah Nomor 01/Pdt.P/Kons/2016/PN.Pbr, memerintahkan Juru Sita/Juru Sita Pengganti melakukan penawaran kepada pihak yang berhak, akan tetapi pihak yang berhak tetap menolak besaran nilai ganti rugi.

b. Dari hasil penawaran yang telah dilakukan oleh Juru Sita/Juru Sita maka dibuatkanlah berita acara sebagai laporan kepada ketua Pengadilan Negeri.

c. Berdasarkan hal tersebut di atas maka dikeluarkanlah Penetapan Nomor 02/Pdt.P/Kons/2016/PN.Pbr yang mengabulkan permohonan pemohon untuk menitipkan/konsinyasi Uang Ganti Kerugian pihak yang berhak di Pengadilan Negeri Pekanbaru.

d. Berita acara penitipan yang ditanda tangani oleh Panitera dengan instansi yang memerlukan tanah dalam hal ini Jimmy Sianipar selaku yang mewakili Kementerian Pekerjaan Umum dan perumahan Rakyat (PUPR).

Untuk lebih jelasnya lamanya waktu proses penitipan/konsinyasi di pengadilan dapat dilihat pada tabel di bawah ini sejak permohonan pemohon konsinyasi sampai selesai serah terima. 
Tabel 2. Pengajuan Permohonan Konsinyasi dan Keluarnya Penetapan Pengadilan Negeri Pekanbaru

\begin{tabular}{|c|c|c|c|c|}
\hline No & Nama & \multirow{2}{*}{$\begin{array}{c}\begin{array}{c}\text { Permohonan } \\
\text { Masuk Pengadilan }\end{array} \\
23 \text { Agustus } 2016\end{array}$} & \multirow{2}{*}{$\begin{array}{c}\begin{array}{c}\text { Penetapan } \\
\text { Pengadilan }\end{array} \\
26 \text { Oktober } 2016\end{array}$} & \multirow{2}{*}{$\begin{array}{c}\begin{array}{c}\text { Nilai UGK yang } \\
\text { Dititipkan } R \boldsymbol{p}\end{array} \\
17.500 .000,00\end{array}$} \\
\hline 1 & Jhoni. S & & & \\
\hline 2 & Jhoni. S & 23 Agustus 2016 & 26 Oktober 2016 & $15.500 .000,00$ \\
\hline 3 & Samsir & 23 Agustus 2016 & 10 Nov 2016 & $11.700 .000,00$ \\
\hline 4 & Basril & 23 Agustus 2016 & 10 Nov 2016 & $4.000 .000,00$ \\
\hline 5 & Nopal & 23 Agustus 2016 & 10 Nov 2016 & $1.181 .000,00$ \\
\hline 6 & Hariadi & 23 Agustus 2016 & 10 Nov 2016 & $9.319 .000,00$ \\
\hline 7 & Edi Supriadi & 23 Agustus 2016 & 10 Nov 2016 & $7.379 .000,00$ \\
\hline \multicolumn{4}{|c|}{ Total UGK yang dititipkan di Pengadilan Negeri Pekanbaru } & $66.579,000,00$ \\
\hline
\end{tabular}

\section{Mekanisme pengambilan uang ganti rugi yang telah dititipkan di pengadilan negeri setempat}

Pengadaan tanah untuk kepentingan umum bertujuan menyediakan tanah bagi pelaksanaan pembangunan guna meningkatkan kesejahteraan dan kemakmuran bagi masyarakat bangsa, dan negara dengan tetap menjamin kepentingan hukum pihak yang berhak. Siapakah pihak yang berhak itu? Pasal 1 Ayat (3) UU PTUP No. 02 Tahun 2012 Jo Perpres 71 Tahun 2012 Pasal 17. Pihak yang berhak adalah pihak yang menguasai atau memiliki objek pengadaan tanah yang dibutuhkan bagi pembangunan untuk kepentingan umum yang meliputi:
a. pemegang hak atas tanah;
b. pemegang pengelolaan;
c. nadzir untuk tanah wakaf;
d. pemilik tanah bekas milik adat;
e. masyarakat hukum adat;
f. pihak yang menguasai tanah negara dengan itikad baik;
g. pemegang dasar penguasaan atas tanah; dan/atau
h. pemilik bangunan, tanaman, atau benda lain yang berkaitan dengan tanah.

Pihak di atas bila menolak bentuk dan/atau besarnya ganti kerugian berdasarkan musyawarah penetapan ganti kerugian, tetapi tidak mengajukan keberatan ke pengadilan negeri atau menolak ganti kerugian berdasarkan putusan pengadilan yang telah memperoleh kekuatan hukum tetap, ganti kerugian dapat diambil di kepaniteraan Pengadilan dalam waktu yang dikehendaki oleh pihak yang berhak disertai dengan surat pengantar dari Ketua Pelaksana Pengadaan Tanah dan 
atau apabila tugas P2T telah berakhir maka Surat Pengantar dari Kepala BPN setempat.

Apabila pihak yang berhak menerima ganti kerugian tidak diketahui keberadaannya, pelaksana pengadaan tanah menyampaikan pemberitahuan mengenai ketidakberadaaan pihak yang berhak secara tertulis kepada camat dan lurah/kepala desa atau nama lainnya. Dalam hal pihak yang berhak telah diketahui keberadaannya, pihak yang berhak mengajukan permohonan kepada Pengadilan untuk mengambil ganti kerugian disertai dengan surat pengantar dari Ketua Pelaksana Pengadaan Tanah.

Dalam hal objek pengadaan tanah sedang menjadi objek perkara di pengadilan atau masih dipersengketakan, ganti kerugian diambil oleh pihak yang berhak di kepaniteraan Pengadilan setelah terdapat putusan pengadilan yang telah berkekuatan hukum tetap atau akta perdamaian, disertai dengan surat pengantar dari Ketua Pelaksana Pengadaan Tanah (P2T)/Badan Pertanahan Nasional yang wilayah hukum pengadaan tanah untuk kepentingan umum.

\section{KESIMPULAN DAN SARAN}

\section{Kesimpulan}

a. Pelaksanaan pembayaran ganti kerugian tanah milik masyarakat, yakni wilayah Kota Pekanbaru pembayaran ganti rugi tanah milik masyarakat telah dilaksanakan pada bulan Januari tahun 2016 untuk keseluruhan sebanyak 133 bidang, yang setuju sebanyak 126 bidang, yang tidak setuju sebanyak 7 bidang. Dalam pelaksanaan pembayaran ganti kerugian lahan/tanah masyarakat tidak terlepas dari berbagai permasalahan diantaranya ada masyarakat yang tidak setuju terhadap besaran nilai ganti kerugian yang telah ditetapkan oleh Kantor Jasa Penilai Publik (KJPP).

b. Tidak terwujudnya kesepakatan mengenai bentuk dan besarnya nilai ganti rugi antara instansi pemerintah yang memerlukan tanah dengan pemegang hak atas tanah yang kemudian dilakukannya konsinyasi ganti rugi ke Pengadilan Negeri setempat. Dengan dikonsinyasikannya ganti rugi ke Pengadilan Negeri tersebut mengakibatkan hak atas tanah langsung dapat diambil oleh instansi pemerintah yang memerlukan tanah dan atas tanah akan menjadi hapus. Dalam hal objek pengadaan tanah masih dipersengketakan di pengadilan dan uang ganti kerugian sudah dititipkan di pengadilan maka ganti kerugian dapat diambil oleh pihak yang berhak di kepaniteraan pengadilan setelah terdapat putusan pengadilan yang telah berkekuatan hukum tetap atau berdasarkan akta perdamaian, disertai dengan surat pengantar dari Ketua Pelaksana Pengadaan Tanah (P2T)/Badan Pertanahan Nasional yang wilayah hukum pengadaan tanah untuk kepentingan umum.

\section{Saran}


a. Kepada pihak yang memiliki hak atas tanah wajib melepaskan tanahnya pada saat pelaksanaan pengadaan tanah bagi pembangunan untuk kepentingan umum. Penyelenggaraan pengadaan tanah untuk kepentingan umum harus memperhatikan keseimbangan antara kepentingan pembangunan dan kepentingan masyarakat. Tetapi, mungkin kurang tersosialisasikan bahwa masyarakat juga memiliki kewajiban untuk melepaskan haknya, yang dimiliki hak atas tanah wajib melepaskan tanahnya pada saat pelaksanaan pengadaan tanah bagi pembangunan untuk kepentingan umum.

b. Pelepasan hak itu harus ada pemberian ganti kerugian atau putusan pengadilan yang telah memperoleh kekuatan hukum tetap. Dalam rangkaian kegiatan yang dilakukan oleh lembaga pengadaan tanah dari tahap perencanaan sampai dengan tahap penyerahan hasil, keterlibatan masyarakat menjadi unsur yang penting. Dalam tahap persiapan pengadaan tanah, hasil konsultasi publik menentukan apakah lokasi yang direncanakan bisa dieksekusi atau instansi harus menentukan lokasi lain. Kalau ada keberatan dari konsultasi publik yang dilakukan, harus ada konsultasi publik ulang. Kalau kemudian ada gugatan, jika dikabulkan pengadilan maka pengadaan tanah tidak bisa dilakukan di lokasi itu. Penyelenggaraan pengadaan tanah untuk kepentingan umum harus memperhatikan keseimbangan antara kepentingan pembangunan dan kepentingan masyarakat.

\section{DAFTAR PUSTAKA}

\section{A. BUKU}

Darmodihardjo, Darji dan Shidarta (2004). Pokok-Pokok Filsafat Hukum, Apa dan Bagaimana Filsafat Hukum Indonesia. Jakarta: PT Gramedia Pustaka Utama.

Harsono, Boedi (1997). Hukum Agraria Indonesia Sejarah Pembentukan UndangUndang Pokok Agraria, Isi dan Pelaksanaannya. Jakarta: Djambatan.

Nonet, Phillipe \& Selznick, Philip (2003). Hukum Responsif Pilihan di Masa Transisi, (judul asli Law and Society in Transition: Toward Responsive Law) terjemahan Rafael EB. Jakarta: HuMa.

Parlindungan, AP (1989). Bunga Rampai Hukum Agraria Serta Pelaksanaan Landrefo. Bandung: Mandar Maju.

Perangin, Effendi (1986). Hukum Agraria di Indonesia Suatu Telaah dari Sudut Pandang Praktisi Hukum. Jakarta: Rajawali Press.

Sitorus, Oloan dan Limbong, Dayat (2004). Pengadaan Tanah untuk Kepentingan Umum. Yogyakarta: Mitra Kebijakan Tanah.

Soemardjono, Maria. S.W. dan Samosir, Martin (2000), Hukum Pertanahan Dalam berbagai Aspek. Medan: Bina Media.

Soimin, Soedaryo (2001), Status Hak \& Pembebasan Tanah, Jakarta: Sinar Grafika. 
Sumardjono, Maria S.W. (2008). Tanah Dalam Perspektif Hak Ekonomi Sosial dan Budaya. Jakarta: Kompas.

Sutedi, Adrian (2008). Implementasi Prinsip Kepentingan Umum Dalam Pengadaan Tanah Untuk Pembangunan. Jakarta: Sinar Grafika.

\section{B. Jurnal}

Endrawati, Netty (2005). Pengadaan Tanah Untuk Kepentingan Pembangunan Nasional Menurut Keppres No. 55 Tahun 1993 jo Keppres No. 34 Tahun 2003. Jurnal Legality, 2(2). 